\title{
Pollen germination and pollen tube growth in Fraxinus pennsylvanica
}

\author{
Dario KREMER ${ }^{1}$ \& Tomislav JemRIĆ ${ }^{2}$ \\ ${ }^{1}$ Faculty of Pharmacy and Biochemistry, University of Zagreb, A. Kovačića 1, 10000 Zagreb, Croatia; tel.: +385-1-4619-422, \\ fax: +385-1-4622-895, e-mail: dkremer@pharma.hr \\ ${ }^{2}$ Faculty of Agriculture, University of Zagreb, Svetošimunska 25, 10000 Zagreb, Croatia; tel.: +385-1-239-3612, e-mail: \\ tjemric@agr.hr
}

\begin{abstract}
With regard to adaptation of green ash (Fraxinus pennsylvanica MARSHALL) to ecological conditions in Croatia, pollen germination and pollen tube length after 2,4 and 6 hours were examined in vitro at $10,15,20$ and $25^{\circ} \mathrm{C}$ during two years 2001 and 2002. Narrow leaved ash (F. angustifolia VAHL) pollen served as a control in 2002. The year, time and temperature, and the interaction between time and temperature were significant for both germination percentage and pollen tube length. Interactions year $\times$ temperature and year $\times$ time were significant for pollen tube length only. The highest germination percentage $\left(17.86 \%\right.$ in 2001 and $19.40 \%$ in 2002) of green ash pollen was at $15^{\circ} \mathrm{C}$ after 6 hours. The pollen tube length was greatest at $20^{\circ} \mathrm{C}(393.46 \mu \mathrm{m})$ in 2001 and $25^{\circ} \mathrm{C}(899.50 \mu \mathrm{m})$ in 2002 after 6 hours. Narrow leaved ash pollen had the highest germination percentage $(19.22 \%)$ at $20^{\circ} \mathrm{C}$ after 6 hours and was significantly reduced at $25^{\circ} \mathrm{C}$. The pollen tube length was greatest at $25^{\circ} \mathrm{C}(518.90 \mu \mathrm{m})$ after 6 hours. It can be concluded that green ash pollen has satisfactory germination in ecological conditions in Croatia and that the optimum temperature for pollen germination is higher than $20^{\circ} \mathrm{C}$.
\end{abstract}

Key words: green ash pollen, exotic species, ecology, pollen germination, pollen tube growth

\section{Introduction}

Green ash (Fraxinus pennsylvanica MARSHALL) is naturally spread in North America from Nova Scotia in the northeast to Northern Florida and central Texas in the south. It grows at altitudes of 0 to $900 \mathrm{~m}$, in moderate warm to moderate cold and humid to semiarid climates. Average rainfalls are 300-1500 mm (250-900 $\mathrm{mm}$ during vegetation period), average snow height is up to $250 \mathrm{~cm}$, and there are 120-180 frost-free days (Miller, 1955; Grimm, 1962; Clausen, 1979; HaRLOW et al., 1996; DiRR, 1998).

Green ash has been present in Croatia for more than 130 years. One herbarium sample with twigs and fruits collected in Lipik (Croatia) in 1877, is in the herbarium of Faculty of Sciences, University of Zagreb (Croatia). ETTINGER (1889, 1892) mentioned this species in the Maksimir public garden, and in the list of plants in Botanical Garden of the Royal University of Franz Josef I in Zagreb. Green ash and white ash ( $F$. americana L.) were used for afforestation of the lowlands on wet sites where the native narrow leaved ash (F. angustifolia VAHL) could not survive. Distribution of green ash in part of lowland forests in Croatia was described by KREMER (2001). The green ash crops regularly in the Botanical Garden of the Faculty of Sciences in Zagreb (JURKOVIć, 1988). At present, the green ash plays an important role in the preparation of habitat for the arrival and survival of native narrow-leaved ash, though its economic function is not substantial (KREMER, 2001).

Green ash has been present in the lowland forests in Croatia for a long time. A question of a possible hybridization with the native narrow leaved ash still persists. The possibility of interspecific hybridization in the genus Fraxinus L. is unclear (SANTAMOUR, 1981).

As a first step for obtaining hybrids and for the estimation of green ash adaptation to the ecological conditions in Croatia, pollen germination and pollen tube elongation were tested in different time and temperature ranges. It was shown that green ash pollen has satisfactory germination at temperatures prevailing during flowering in the ecological conditions of Croatia.

\section{Material and methods}

Pollen was collected when the majority of male flowers had dehisced anthers from 10 randomly selected trees of green ash in 2001 and 2002 in Zagreb (Croatia). The pollen of 10 trees was mixed to obtain random samples. As control, the pollen of 10 narrow leaved ash trees was collected in 2002 in Zagreb. 
According to Koppen's classification the climate of Zagreb belongs to the climate type Cfwbx. This is a moderately warm rainy climate without a dry period and with precipitation uniformly distributed throughout the year. The mean temperature of the coldest month (January) does not drop below $-0.4^{\circ} \mathrm{C}$, while the mean temperature of the warmest month (July) usually does not exceed $21.4^{\circ} \mathrm{C}$. Annual precipitation amounts to $900 \mathrm{~mm}$ (up to $489 \mathrm{~mm}$ in the vegetation period), while the annual relative air humidity ranges between 77 and 92\% (SEletKović, 1996).

Pollen germination was performed in Petri dishes in a medium of $1 \%$ agar-agar and $10 \%$ sucrose. According to Nikolaeva (1962, cited by Miksche, 1976) the pollen of common ash ( $F$. excelsior L.) and black ash ( $F$. ornus L.) had the best germination on a medium with $15 \%$ and $5 \%$ sucrose, respectively. So we assumed that green ash pollen might have good germination at sucrose concentrations between these values. Pollen was added to the Petri dishes with the sucrose-agar medium and germination was performed at $10,15,20$ and $25^{\circ} \mathrm{C}$ for 2,4 and 6 hours. For each temperature $\times$ time combination we used three replicates. After achieving the appropriate germination time, further germination was halted with formaline. The germination percentage and pollen tube length were examined with the microscope Carl Zeiss GmbH., Germany at 50× magnification using a measuring scale. Germination was examined in 10 randomly selected places in each Petri dish. Also, twenty randomly selected pollen tubes were measured in each Petri dish. Statistical analysis was performed using SAS Software (SAS Institute, Cary, NC, USA) and the GLM Procedure, and Duncan multiple range test at the $p=0.05$ level. Before analysis, data were transformed using logarithmic transformation.

Plant growth and development is proportional to biological time, or thermal time, which can be defined as the integral of the product of time and temperature above a certain threshold. This constitutes the concept of units of growing degree days (GDD), calculated as the sum of differences between the temperature of a certain time period and a threshold temperature (base temperature) for each period after a given starting date. The concept is simple and accurate in predicting phenological stages and has been used to forecast the main stages of plant development (OLIVEIRA, 1998), particularly for predicting vegetable maturity in the processing industry, for predicting the completion of rest, predicting bloom, and for predicting harvest dates for tree fruits (RICHARDSON et al., 1975; EISENSMITH et al., 1980). For this reason, GDD were used to explain the effect of year on dehiscence of anthers and pollen germination. They were calculated for the period from 1 February (of the current year) to the phenophase of beginning, culmination and end of flowering. The GDD were obtained using standard method: GDD $=\left\{\left(t_{\max }+t_{\min }\right) / 2\right\}-$ base temperature (PERRY et al., 1986). The temperature of $4^{\circ} \mathrm{C}$ was used as the base temperature.

\section{Results}

Year, temperature, time and the interaction between temperature and time had a significant effect on both pollen germination and pollen tube growth in green ash. However, interactions between year and temperature, year and time only had a significant effect on pollen

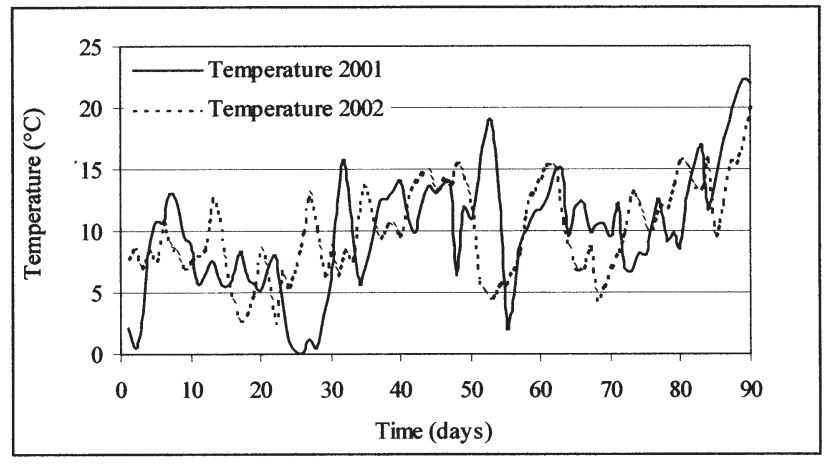

Fig. 1 Mean air temperatures from February 1 to May 1, (period prior to and during the flowering of F. pennsylvanica) in 2001 and 2002 in Zagreb, Croatia.

Table 1. Effect of year, temperature and time on pollen germination of $F$. pennsylvanica.

\begin{tabular}{ccc}
\hline \multirow{2}{*}{$\begin{array}{c}\text { Source } \\
\text { of variability }\end{array}$} & Germination & Pollen tube length \\
\cline { 2 - 3 } & \multicolumn{2}{c}{$P$} \\
\hline Year & 0.0001 & 0.0001 \\
Temperature & 0.0001 & 0.0001 \\
Time & 0.0001 & 0.0001 \\
Temperature $\times$ Time & 0.0001 & 0.0051 \\
Year $\times$ Temperature & 0.0810 & 0.0002 \\
Year $\times$ Time & 0.1077 & 0.0003 \\
Year $\times$ Temperature $\times$ Time & 0.5240 & 0.1256 \\
\hline
\end{tabular}

Table 2. Phenological data for flowering of $F$. pennsylvanica in Zagreb in 2001 and 2002.

\begin{tabular}{cccc}
\hline $\begin{array}{l}\text { Phenophase } \\
\text { of flowering }\end{array}$ & Date & $\begin{array}{c}\text { Days from } \\
1^{\text {st }} \text { February }\end{array}$ & GDD \\
\hline & 2001 & & \\
\hline Beginning & 12.4. & 71 & 369 \\
Culmination & 24.4. & 82 & 444 \\
End & 1.5. & 89 & 530 \\
\hline & 2002 & & \\
\hline Beginning & 18.3. & 46 & 229 \\
Culmination & 8.4. & 67 & 360 \\
End & 15.4. & 74 & 393 \\
\hline
\end{tabular}

Note: GDD = growing degree days.

tube length. The interaction among year, temperature and time had no significant effect (Tab. 1). The effect of year can be explained by the difference in air temperature for the period before flowering in 2001 and 2002 (Fig. 1, Tab. 2).

Time, temperature, and their interaction had a significant effect on pollen germination and pollen tube length of green ash in 2001. In 2002, temperature and time interaction had no significant effect on pollen tube 
Table 3. Effect of time and temperature on pollen germination of F. pennsylvanica in 2001 and 2002 and F. angustifolia in 2002.

\begin{tabular}{|c|c|c|}
\hline \multirow{2}{*}{$\begin{array}{c}\text { Source } \\
\text { of variability }\end{array}$} & Germination & Pollen tube length \\
\hline & \multicolumn{2}{|r|}{$P$} \\
\hline & \multicolumn{2}{|c|}{ F. pennsylvanica } \\
\hline & \multicolumn{2}{|r|}{2001} \\
\hline Temperature & 0.0001 & 0.0001 \\
\hline Time & 0.0001 & 0.0001 \\
\hline Temperature $\times$ Time & 0.0001 & 0.0008 \\
\hline \multicolumn{3}{|c|}{2002} \\
\hline Temperature & 0.0001 & 0.0001 \\
\hline Time & 0.0001 & 0.0001 \\
\hline Temperature $\times$ Time & 0.0001 & 0.712 \\
\hline & \multicolumn{2}{|c|}{ F. angustifolia } \\
\hline & \multicolumn{2}{|r|}{2002} \\
\hline Temperature & 0.0001 & 0.0001 \\
\hline Time & 0.0001 & 0.0001 \\
\hline Temperature $\times$ Time & 0.0001 & 0.0003 \\
\hline
\end{tabular}

length (Tab. 3). Such results justify performing separate statistical analysis for time and temperature (Tabs 4, $5)$.

In green ash (Tab. 4) there was a trend of increasing both the germination percentage and pollen tube length with increasing temperature and time. The highest germination percentage was at $15^{\circ} \mathrm{C}$ after 6 hours in both years (17.86\% in 2001 and $19.40 \%$ in 2002) and there was no significant difference in comparison to 20 and $25^{\circ} \mathrm{C}$ in 2001 . In 2002 there was a significant difference between 15 and $25^{\circ} \mathrm{C}$ (Tab. 4). At $10^{\circ} \mathrm{C}$, the germination percentage was very low in both years.

Time and temperature affected pollen tube length to a greater extent than the germination percentage. The longest tubes $(899.50 \mu \mathrm{m}$ in 2002) in green ash were at $25^{\circ} \mathrm{C}$ after $6 \mathrm{~h}$. There was a significant difference with all other temperatures after $6 \mathrm{~h}$, except in 2001 when the maximum $(393.46 \mu \mathrm{m})$ was attained after $6 \mathrm{~h}$ at $20^{\circ} \mathrm{C}$, but with no difference at $25^{\circ} \mathrm{C}$ (Tab. 4$)$.

In narrow leaved ash, temperature, time, and their interaction had a significant effect on pollen germination and pollen tube length (Tab. 3). The highest germination percentage $(19.22 \%)$ was at $20^{\circ} \mathrm{C}$ after 6 hours and rapidly decreased at $25^{\circ} \mathrm{C}$ (Tab. 5). The greatest pollen tube length $(518.90 \mu \mathrm{m})$ was noted after 6 hours at $25^{\circ} \mathrm{C}$ without a significant difference at $20^{\circ} \mathrm{C}$.

\section{Discussion}

The optimal temperature for green ash pollen germination is between 20 and $25^{\circ} \mathrm{C}$ (Tab. 4). Based on pollen tube lengths, the optimal temperature is closer to $25^{\circ} \mathrm{C}$.
Table 4. Pollen germination and pollen tube length in F. pennsylvanica after 2,4 and 6 hours at $10,15,20$ and $25^{\circ} \mathrm{C}$ in 2001 and 2002.

\begin{tabular}{|c|c|c|c|}
\hline \multirow{3}{*}{$\begin{array}{l}\text { Temperature } \\
\left({ }^{\circ} \mathrm{C}\right)\end{array}$} & \multicolumn{3}{|c|}{ Time of germination $(\mathrm{h})$} \\
\hline & 2 & 4 & 6 \\
\hline & \multicolumn{3}{|c|}{ Pollen germination (\%) } \\
\hline & \multicolumn{3}{|c|}{2001} \\
\hline 10 & $0.83 \mathrm{Ba}$ & $1.41 \mathrm{Ca}$ & $1.66 \mathrm{Ba}$ \\
\hline 15 & $0.73 \mathrm{Bc}$ & $10.48 \mathrm{Ab}$ & $17.86 \mathrm{Aa}$ \\
\hline 20 & $7.16 \mathrm{Aa}$ & $11.59 \mathrm{Aa}$ & $13.03 \mathrm{Aa}$ \\
\hline \multirow[t]{2}{*}{25} & $5.72 \mathrm{Ab}$ & $6.39 \mathrm{Bb}$ & $12.36 \mathrm{Aa}$ \\
\hline & \multicolumn{3}{|c|}{2002} \\
\hline 10 & $1.33 \mathrm{Bb}$ & $2.21 \mathrm{Ca}$ & $2.60 \mathrm{Ca}$ \\
\hline 15 & $1.73 \mathrm{Bb}$ & $17.38 \mathrm{Aa}$ & $19.40 \mathrm{Aa}$ \\
\hline 20 & $8.35 \mathrm{Aa}$ & $10.59 \mathrm{Ba}$ & $13.31 \mathrm{ABa}$ \\
\hline \multirow[t]{3}{*}{25} & $12.87 \mathrm{Aa}$ & $10.29 \mathrm{Ba}$ & $11.52 \mathrm{Ba}$ \\
\hline & \multicolumn{3}{|c|}{ Pollen tube length $(\mu \mathrm{m})$} \\
\hline & \multicolumn{3}{|c|}{2001} \\
\hline 10 & $10.97 \mathrm{Db}$ & $26.68 \mathrm{Da}$ & $30.12 \mathrm{Ca}$ \\
\hline 15 & $23.58 \mathrm{Cb}$ & $64.30 \mathrm{Cb}$ & $145.17 \mathrm{Ba}$ \\
\hline 20 & $40.84 \mathrm{Bc}$ & $156.57 \mathrm{Bb}$ & $393.46 \mathrm{Aa}$ \\
\hline \multirow[t]{2}{*}{25} & $87.30 \mathrm{Ab}$ & $353.26 \mathrm{Aa}$ & $355.75 \mathrm{Aa}$ \\
\hline & \multicolumn{3}{|c|}{2002} \\
\hline 10 & $14.16 \mathrm{Dc}$ & $21.13 \mathrm{Cb}$ & $52.16 \mathrm{Da}$ \\
\hline 15 & $67.62 \mathrm{Cc}$ & $145.77 \mathrm{Bb}$ & $305.35 \mathrm{Ca}$ \\
\hline 20 & $100.87 \mathrm{Bc}$ & $164.54 \mathrm{Bb}$ & $419.47 \mathrm{Ba}$ \\
\hline 25 & $269.37 \mathrm{Ac}$ & $446.00 \mathrm{Ab}$ & $899.50 \mathrm{Aa}$ \\
\hline
\end{tabular}

Note: values marked with the same letter are not significant at $p \leq 0.05$ according to Duncan's multiple range test; capital letter $=$ difference in the column; small letter $=$ difference in the row.

As opposed to green ash, narrow leaved ash has an optimal temperature closer to $20^{\circ} \mathrm{C}$ since its germination percentage was higher at this temperature. Pollen tube length was lower at $20^{\circ} \mathrm{C}$, though the difference in comparison to $25^{\circ} \mathrm{C}$ was not significant (Tab. 5). For specifying the optimal temperature of germination, the determination of the pollen tube growth rate could be useful. Measurements should be done on the same pollen grain, however such an approach is connected with technical difficulties and as such, there is no reference for the pollen tube growth rate. There are only a few reports on pollen germination and pollen tube length in the genus Fraxinus. After $8 \mathrm{~h}$ of incubation at $25^{\circ} \mathrm{C}$ on the media with $5 \%$ sucrose, the average germination percentage of black ash pollen was $31 \%$ and pollen tube length was $817 \mu \mathrm{m}$ (PAOLETTI, 1992). IshIDA \& HiURA (1998) achieved satisfactory pollen germination of F. lanuginosa KoIDZ. on a media of $5 \%$ and $10 \%$ sucrose. The mean pollen germination in vitro (after 24 hours at room temperature) for hermaphrodite trees was $0.6 \%$ on the media with $10 \%$ sucrose and $1.4 \%$ on the media with $5 \%$ sucrose. For male trees, the 
Table 5. Pollen germination and pollen tube length in $F$. angustifolia after 2,4 and 6 hours at $10,15,20$ and $25^{\circ} \mathrm{C}$ in 2002 .

\begin{tabular}{|c|c|c|c|}
\hline \multirow{3}{*}{$\begin{array}{l}\text { Temperature } \\
\left({ }^{\circ} \mathrm{C}\right)\end{array}$} & \multicolumn{3}{|c|}{ Time of germination $(\mathrm{h})$} \\
\hline & 2 & 4 & 6 \\
\hline & \multicolumn{3}{|c|}{ Pollen germination $(\%)$} \\
\hline & \multicolumn{3}{|c|}{2002} \\
\hline 10 & $0.65 \mathrm{Cb}$ & $2.93 \mathrm{Ba}$ & $4.70 \mathrm{Ba}$ \\
\hline 15 & $12.33 \mathrm{Ab}$ & $14.86 \mathrm{Aa}$ & $14.86 \mathrm{Aa}$ \\
\hline 20 & $8.85 \mathrm{Bb}$ & $12.65 \mathrm{Aab}$ & $19.22 \mathrm{Aa}$ \\
\hline 25 & $4.93 \mathrm{Ba}$ & 7.93 Aab & $9.49 \mathrm{Bb}$ \\
\hline
\end{tabular}

Pollen tube length $(\mu \mathrm{m})$

\begin{tabular}{rrrr}
\hline \multicolumn{4}{c}{2002} \\
\hline 10 & $17.31 \mathrm{Dc}$ & $61.66 \mathrm{Cb}$ & $138.38 \mathrm{Ba}$ \\
15 & $66.45 \mathrm{Cb}$ & $189.75 \mathrm{Ba}$ & $207.21 \mathrm{Ba}$ \\
20 & $131.67 \mathrm{Ba}$ & $228.49 \mathrm{Bb}$ & $467.32 \mathrm{Ac}$ \\
25 & $196.11 \mathrm{Ac}$ & $349.94 \mathrm{Ab}$ & $518.90 \mathrm{Aa}$ \\
\hline
\end{tabular}

Note: values marked with the same letter are not significant at $p \leq 0.05$ according to Duncan's multiple range test; big letter $=$ difference in the column; small letter $=$ difference in the row.

germination percentages were $1.7 \%$ and $4.8 \%$, respectively.

Based on the literature data and the results of this study, it can be concluded that ash species have very diverse percentages of pollen germination.

Future research should be extended to other important flowering and fruit set characteristics (longevity of ovule, fruit set, etc.) which have been studied in great detail in fruit trees from the family Rosaceae, (SHURAKi \& Sedgley, 1994; Egea \& Burgos, 1995, 2000; Cerović et al., 2000; OukABli et al., 2000; Jonke et al., 2003). It is hard to make a comparison of these data with the results for the genus Fraxinus (Oleaceae) since these two families have completely different pollination strategies, pollen production and pollen loads to stigmas.

From the results of this study, it can be concluded that the introduced green ash produces pollen of a satisfactory germination for Croatian climate conditions. The optimal temperature for pollen germination is closer to 25 than to $20^{\circ} \mathrm{C}$. The small germination percentage at $10^{\circ} \mathrm{C}$ indicates questionable success of hybridization at low temperatures. As such, hybridization should be conducted during the highest daily air temperature in the part of crown, which is exposed to direct sunlight.

\section{Acknowledgements}

The authors wish to thank Prof. Dr. Bogdan CvJEtKović, Tihomir MiličEvić, Mrs. Nelly MAJCEN-PrAćINEC and Ms. Davorka OzMEc from the Department of Phytopathology, Faculty of Agriculture, University of Zagreb for their technical assistance. We also wish to thank Dr. Jelena TRAJKOVIĆ of the Faculty of Forestry, University of Zagreb.

\section{References}

Cerović, R., Ružić, D. \& Mičıć, N. 2000. Viability of plum ovules at different temperatures. Ann. Appl. Biol. 137: 5358.

Clausen, K.E. 1979. Mini-monograph on Fraxinus pennsylvanica MARsh., pp. 195-208. In: Proc. of FAO technical consultation on fast-growing plantation broadleaved trees for mediterranean and temperate zones, Lisbon, FO: FGB-79$6 / 8$.

DirR, M.A. 1998. Manual of Woody Landscape Plants. Stipes Publishing L.L.C., Champaign, Illinois, 1187 pp.

EgeA, J. \& Burgos, L. 1995. Double kerneled fruits in almond [Prunus dulcis (MiLL)] as related to pre-blossom temperatures. Ann. Appl. Biol. 126: 163-168.

EgeA, J. \& Burgos, L. 2000. Ovule differences between singlekernelled and double-kernelled fruits in almond (Prunus dulcis). Ann. Appl. Biol. 136: 291-295.

Eisensmith, S.P., Jones, A.L. \& Flore, J.A. 1980. Predicting leaf emergence of 'Montmorency' sour cherry from degree-day accumulations. J. Amer. Soc. Hort. Sci. 101: 75-78.

Ettinger, J. 1889. Priegled drveća i grmlja od osobite vrsti, koje raste u perivoju Maksimir. (Review of special trees and shrubs which grow in public garden Maksimir). Šum. list, Zagreb, 13: 112-119.

EtTinger, J. 1892. Botanički vrt kr. sveučilišta Franje Josipa I u Zagrebu. (Botanical garden of Royal university Franjo Josip 1 in Zagreb). Šum. list, Zagreb, 16: 409-422.

Grimm, W.C. 1962. The Book of Trees. Hawthorn Books Inc., New York, 493 pp.

Harlow, W.M., Harrar, E.S. Hardin, J.W. \& White, F.M. 1996. Textbook of Dendrology. Mcgraw-Hill Inc., New York, $534 \mathrm{pp}$.

IsHidA, K. \& HiURA, T. 1998. Pollen fertility and flowering phenology in an androdioecious tree, Fraxinus lanuginosa (Oleaceae), in Hokkaido, Japan. Int. J. Plant. Sci. 159: 941947.

Jonke, A., Jemric, T., Pavičic, N. \& Blaškovic, D. 2003. Klijavost polena jabuke i utjecaj na zametanje plodova sorte Golden Delicious klon B. (Pollen germinability of apple pollenizers and their effect on fruit set in Golden Delicious clone B). Sjemenarstvo, Zagreb, 20: 29-36.

JuRKOVIĆ, M. 1988. Fruktifikacija i subspontano razmnožavanje drvenastih egzota $\mathrm{u}$ arboretumu Botaničkog vrta u Zagrebu. (Fructification and subspontaneous reproduction of exotic woody plants in the Arboretum of Botanical Garden - Faculty of Sciences Zagreb). Šum. list, Zagreb, 112: 327-334.

Kremer, D. 2001. Zastupljenost američkog bijelog jasena (Fraxinus americana L.) i pensilvanskog jasena (Fraxinus pennsylvanica MARshall) u Pokuplju, Posavini i dijelu Podunavlja. (Representation of white ash (Fraxinus americana L.) and green ash (Fraxinus pennsylvanica MARSHALL) in Kupa river basin, Sava river basin, and Danube basin). M.Sc. Thesis, Univ. of Zagreb, $227 \mathrm{pp}$.

Miksche, J.P. 1976. Modern methods in forest genetics. SpringerVerlag, Berlin, Heidelberg, New York, 288 pp.

Miller, G.N. 1955. The Genus Fraxinus, The Ashes, in North America, North of Mexico. Cornell Univ. Agr. Exp. Sta. Mem. 335: $1-64$.

Oliveira, M. 1998. Calculation of budbreak and flowering base temperatures for Vitis vinifer cv. Touriga Francesa in the Douro Region of Portugal. Am. J. Enol. Vitic. 46: 74-78.

Oukabli, A., Lansari, A. Wallali, D.L. Abousalim, A. Egea, J. \& Michaux-Ferriere, N. 2000. Self and cross pollination effects on pollen tube growth and fertilization in self-compatible almond Prunus dulcis 'Tuono'. J. Hortic. Sci. Biotechnol. 75: 739-744. 
Paoletti, E. 1994. Effects of acidity and detergent on in vitro pollen germination and tube growth in forest tree species. Tree Physiol. 10: 357-366.

Perry, K.B., Wehner, T.C. \& Johnson, G.L. 1986. Comparison of 14 methods to determine heat unit requirements for cucumber harvest. HortScience 21: 419-423.

Richardson, E.A., Seeley, S.D., Walker, D.R., Anderson, J.L., \& Aschroft, G.L. 1975. Pheno-climatology of spring peach bud development. HortScience 10: 236-237.

SANTAmour, F.S. Jr. 1981. Flavonoids and Coumarins in Fraxinus and their potential utility in hybrid verification, pp. 4246. In: DeHayes, D.H. (ed.), Proc. of $27^{\text {th }}$ Northeast. For. Tree Improv. Conf., Sch. of Natur. Resour., Univ. of Vermont, Burlington, Vermont.
Seletković, Z. 1996. Climate of pedunculate oak forests, pp. 71-82. In: Klepac, D. (ed.), Pedunculate oak in Croatia, HAZU and "Croatian forest", Vinkovci, Zagreb.

Shuraki, Y.D. \& Sedgley, M. 1994. Effect of pistil age and pollen parent on pollen tube growth and fruit production of pistachio. J. Hortic. Sci. 69: 1019-1027.

Received April 24, 2005 Accepted Nov. 10, 2005 